\title{
A Debreceni Egyetem elektronikus Archívuma (DEA)
}

\section{Impresszum}

ADEA a Debreceni Egyetem intézményi repozitóriuma - s mint ilyen, definíció szerint az egyetemen született tudományos publikációk gyüjtésére, szolgáltatására, archiválására és a nyílt hozzáférés biztosítására alkalmas rendszer.

A Debreceni Egyetem Egyetemi és Nemzeti Könyvtár (DEENK) az egyetem Szilárdtest Fizikai Tanszékének kezdeményezését átvállalva kezdte el 2006 tavaszán az intézményi elektronikus archívum kialakítását (http://[-] dea.lib.unideb.hu), melynek üzemszerü müködtetésére hivatalos felhatalmazást 2006 novemberében kapott. A DEENK-nek a Debreceni Egyetem Szenátusa által elfogadott „Müködési Rend”-jében az alapszolgáltatások között szerepel a DEA fejlesztése, gondozása és üzemeltetése. Ezzel megtettük az első jelentős lépést ahhoz, hogy az Archívum az Egyetem infrastruktúrájának szerves részévé, a tudományos munkafolyamat alapelemévé váljon.

A kezdeményező tanszék a DSpace keretrendszert választotta, ezért a DEA ezt a szoftvert használja. Az egyetemen beszerzésre választott tekintélyes méretü tárhely alkalmas az összegyüjtött dokumentumok szolgáltatására és hosszú távú tárolására. A rendelkezésre álló 4 terabájtnyi tárolókapacitásból jelenleg 1,7 TB-t foglalnak el az archivált anyagok.

$\mathrm{Az}$ intézményi repozitórium fenntartása és hatékony müködtetése összehangolt csapatmunkát igényel. A zökkenőmentes napi működtetés az adminisztrációért felelős technikai szakember hatásköre: gyüjtemények kialakítása és kezelése, a jogosultságok meghatározása és beállítása, a könyvtárosok és felhasználók képzése és tájékoztatása. Könyvtárosok foglalkoznak a felhasználókkal való kapcsolattartással és kapcsolatépítéssel, illetve a repozitórium egyetemi, országos és nemzetközi szintü népszerüsítésével. A korszerü, felhasználói igényeket és a technológiai újításokat is követő szolgáltatás fenntartását a csapatba részmunkaidöben kapcsolódó szoftverfejlesztő munkatárs biztosítja, míg a DEA technikai üzemeltetése az egyetem informatikai infrastruktúrájába ágyazva az Informatikai Szolgáltató Központ feladata.

A DEA müködésének tizedik évfordulóját számos változással ünnepeltük meg: verziófrissítést, új arculat kialakítását és az archívum szerkezetének radikális újragondolását végeztük el. 


\section{Szerkezet}

A DSpace fejlesztői elgondolásának megfelelően a DEA szerkezete kategóriákra, alkategóriákra és gyüjteményekre tagolódik. A DEA müködésének első évtizedében egyre sokasodtak a különböző igények szerint kialakított gyüjtemények, melyek alapvetően az egyetem szerkezetét követték, s lassan átláthatatlanná tették az archívum egészét.

2014-ben az Egyetem felépítési rendjét követő struktúrát dokumentum-centrikus rendszerezés váltotta fel. Az egyes gyüjteményeket önálló szolgáltatási felülettel láttuk el, így a doktori dolgozatok, hallgatói dolgozatok, egyetemi publikációk és digitalizált tartalmaink közvetlen eléréssel rendelkeznek. Igényesen kialakított egységes dizájn öleli egybe a gyüjteményeket, ugyanakkor eltérő színvilág jelzi azok határait. Ez az alapvetően felhasználó szempontú szerkezeti felállás lehetővé teszi azt is, hogy az Egyetem struktúrájában lezajló változásoktól függetlenül müködjön a repozitóriumi tartalom-menedzsment.

\section{Tartalom}

ADEA-ban közreadható dokumentumok jogi kereteit a Szerzői jogi törvény (Szjt. 30. §, Szjt. 38. § (5)) és kapcsolódó Kormányrendelet (117/2004. (IV. 28.) Kormányrendelet), a doktori dolgozatok nyilvánosságáról rendelkező utasítások (51/2001. (IV.3) Kormányrendelet 40-41.§, 33/2007. (III. 7.) Kormányrendelet 11. §), a Felsőoktatási törvény (2011. évi CCIV. törvény a nemzeti felsőoktatásról), valamint a Debreceni Egyetem vonatkozó szabályzatai (Doktori szabályzat, Tanulmányi- és Vizsgaszabályzat, Szellemitulajdon-kezelési szabályzat, Szerzői jogi szabályzat és publikációs irányelvek) jelölik ki. Az archívumban tárolható és szolgáltatható dokumentumok körét a felsorolt rendelkezések figyelembe vételével határoztuk meg.

Digitális Könyvtár: a DEENK-ben a folyamatos (tervszerü és projektrendszerü) digitalizálási tevékenység során körülbelül százezer oldalnyi könyv, folyóirat, színlap és kotta digitalizálását végeztük el. Ezek kezelése, szolgáltatása azonban a mennyiségi növekedés és a különböző hozzáférési korlátok miatt nehézkessé vált. Az Szjt. 38. § (5) bek., illetve ennek kiegészítése, a 117/2004. (IV. 28.) Kormányrendelettel lehetővé teszi, hogy a könyvtárak a gyüjteményükben lévő müveket saját helyiségeikben az ezzel a céllal üzembe állított számítógépes képernyőkön tudományos kutatás, vagy egyéni tanulás céljára a nyilvánosság bizonyos tagjai számára szabadon megjeleníthessék. A DEA autentikációs rendszerével, és jól defi- 
niálható hozzáférési szintjeivel megfelelönek bizonyult digitalizált anyagaink, valamint az említett Kormányrendelet értelmében megjeleníthetö dokumentumaink szolgáltatására.

Disszertációk és tézisek: Nemzetközi szinten kiemelkedö, hogy hazánkban már a 2000-es évek elejétöl születtek rendeletek a doktori diszszertációk nyilvános eléréséről, melyet aktuálisan a Felsőoktatási törvény szabályoz oly módon, hogy a doktori értekezés és tézisei egy nyomtatott és egy elektronikus adathordozón rögzített példányának a felsőoktatási intézmény központi könyvtárában történő elhelyezését elöírja. E rendelkezés értelmében a DEA-ban tárolhatók és korlátozás nélkül szolgáltathatók a Debreceni Egyetem doktori iskoláiban elfogadott disszertációk és azok tézisei. A nyilvánosságra hozatal részletes szabályait a doktori szabályzat határozza meg a Debreceni Egyetemen, és e szabályzat értelmében a DEA a doktori fokozatszerzési folyamat részévé vált.

Hallgatói dolgozatok: A Debreceni Egyetemen a Tanulmányi és vizsgaszabályzat rendelkezése szerint a hallgatók számára a tanulmányaikat lezáró szakdolgozat, illetve diplomamunka benyújtását a papíralapú változat mellett kötelező elektronikusan is megtenni. A dolgozatok DEA-ba történő feltöltése az államvizsgára bocsátás feltétele, annak ellenőrzése beépült a karok adminisztratív folyamataiba. Az elektronikus dolgozatok használatát a karok rendelkezése alapján biztosítjuk a DEA-ban, jellemzően a Debreceni Egyetem területéröl. A titkosított szakdolgozatok feltöltésre kerülnek, ám nem érhetők el a felhasználók számára. Az elektronikus forma megőrzéséröl és nyilvántartásáról a DEA üzemeltetőjeként a DEENK gondoskodik.

Publikációk: A DEA-ban a nyílt hozzáférés (open access) eredeti szellemiségének megfelelően tároljuk és szolgáltatjuk az Egyetemen dolgozók kutatási eredményeit a kiadói copyright-politika és a személyes rendelkezések maximális tiszteletben tartásával. 2015-ben a Debreceni Egyetem egységes szabályzatban foglalt állást a publikált tudományos eredményeink gyüjtéséről, valamint a nyílt hozzáférésről. A Szerzői jogi szabályzat és publikációs irányelvek címủ szabályzat eredményeként 2016 elejére közel 3000 cikkhez biztosítunk nyílt hozzáférést a felhasználók számára a DEA Publikációk gyűjteményében.

További gyüjtemények

Oktatási segédletek, elöadásanyagok: Ennek a gyüjteménynek a kihasználtsága nem számottevő jelen pillanatban. Gyakran keresik a könyvtárban 
az egyes intézeti honlapokon elszórtan található elöadásanyagokat, jegyzeteket, vizsgakérdéseket. Ezek ideális, rendszerezett gyüjtőhelye lehet a jövőben az intézményi archívum.

Intézményi dokumentáció: A DEA-ban biztonságosan archiválhatók az egyetemi karok évkönyvei és egyéb dokumentációi.

\section{Biztonság, hozzáférési szintek}

Dokumentumokat az arra jogosult használók tölthetnek fel az archívum gyüjteményeibe. A feltöltéskor alapvető metaadatok (szerző, cím, sorozat, ISBN, ISSN, dokumentumtípus, nyelv, kulcsszavak, összefoglaló stb.) megadása és a dokumentum(ok) feltöltése után egy kötelező (a gyüjtemény egészére vonatkozó) és egy választható (Creative Commons) licenc csatolható a dokumentumhoz. Valamennyi tételt független elérést lehetővé tevő egyedi azonosítóval látunk el, amely nem érzékeny a dokumentum későbbi helyzetváltoztatására. A feltöltést végző személy e-mailben automatikus értesítést kap a müvelet sikeréröl. A hallgatói dolgozatok és a doktori értekezések esetében csoportos feltöltési jogosultságot a tanulmányi rendszer adatai alapján automatikusan kapnak a hallgatók.

Az repozitórium tartalmának elérését három szintre korlátoztuk. Az első szinten csupán a dokumentum rövid adatai (cím, szerző, a feltöltés ideje) tekinthetők meg, a második szinten hozzáférhetünk valamennyi metaadatához, a harmadik szinten a teljes szöveg is letölthető. A hozzáférési szinteket IP-alapú, illetve jelszavas (LDAP) bejelentkezéssel kontrolláljuk. Feltöltési, illetve elérési jogosultságot egyénenként vagy csoportonként adhat az adminisztrátor.

Az elérés korlátozása nem egyezik meg a nyílt hozzáférés alapelvével, de a technológiát kihasználva más, csak meghatározott felhasználói csoportok számára elérhető tartalmakat is szolgáltathatunk (szakdolgozatok, egyes szakok hallgatóinak készített oktatási anyagok, a könyvtárnak az Szjt. értelmében digitalizált dokumentumai). Ezeknek a tartalmaknak, illetve metaadataiknak az elérhetőségét a regiszter-szolgáltatásokból az adatbázis OAI-PMH kompatibilitása teszi lehetővé, amely a http://re.cs.uct.ac.za oldalon tesztelhető. A DEA-t a Google indexeli, a dokumentumok teljes szövegéből is ad találatokat. 


\section{Kapcsolatok}

Egyetemi informatikai rendszer

Az Egyetemi és Nemzeti Könyvtár elsőrendủ szempontja, hogy egységes szolgáltatási rendszert alakítson ki, amely felhasználóbarát funkcióival hatékonyan reagál az egyetemi oktatók, kutatók és diákok által támasztott igényekre, gördülékenyen integrálható a kutatási, oktatási folyamatokba.

A repozitórium összeköttetésben áll az Egyetem Neptun tanulmányi rendszerével, amely hallgatói nyilvántartás mellett az oktatásszervezéssel kapcsolatos adminisztratív adatok tárolását is szolgálja. A repozitóriumba való bejelentkezéskor a rendszer azonosítja a felhasználók egyetemi státuszát és jogosultsági köreit.

2014-ben a DEA Publikációk gyüjteményének tartalmát integráltuk az iDEa Tudóstér (https://tudoster.idea.unideb.hu) szolgáltatásba, ahol a bibliográfiai keresések találati listájából vagy a kutatói-, illetve tanszékiintézeti profilokból közvetlenül megnyithatók az elérhető teljes szövegek. Egyre bővül a pályázatokhoz, kutatási projektekhez kapcsolódó profilok és publikációs listák száma. A profilokban többek között a feltöltött, illetve elérhető teljes szövegek számáról is találunk adatokat.

A korábban elkülönülő szolgáltatások összekapcsolása a Tudóstérben egységes felhasználói élményt nyújt, az adatbeviteltől a szerzői vagy tanszéki, intézeti publikációs profilok megjelenítésén át a teljes szövegek eléréséig.

A DEA háttértárként szolgál további szolgáltatások számára is, így a Debreceni Egyetem tehetséggondozó programjának (DETEP) keretében született dolgozatok közül a program által fejlesztett keresőfelületen lehet válogatni, de a háttér-tárolást a dokumentumok részére a DEA adja. A Debreceni Egyetemi Kiadó archív anyagai is a DEA-ban tárolódnak, amely lehetővé teszi a cikkek és könyvek hosszú távú megőrzését, és állandó azonosítását Handle-szám használatával.

\section{Kapcsolat nemzetközi rendszerekkel}

A Debreceni Egyetem Egyetemi és Nemzeti Könyvtár számos olyan nemzetközi program és projekt aktív résztvevője, amelyek a nemzetközi repozitórium-hálózat fejlesztését, az akadálymentes szabványos adatcserét és információhoz való korlátlan hozzáférést tüzték ki célul. A szóban forgó infrastrukturális együttmüködések mindegyikében kulcsszerepet játszik a DEA. 
DART-Europe (http://www.dart-europe.eu): A projekt célja az európai doktori értekezések összegyüjtése és közzététele egy közös platformon keresztül. Az egyik első olyan európai projekt, mely közös adatszolgáltatást célzott meg több repozitórium tartalmára alapozva. A kompatibilitási feltételek között szerepel, hogy (1) az adatokat OAI-PMH protokollon keresztül kell átadni, (2) a metaadat-szerkezetnek a Dublin Core sémát kell követnie, (3) a doktori anyagokat egy külön halmazon (set) keresztül kell arathatóvá tenni, ha mást is tartalmaz az adattár, és (4) a teljes szövegnek nyíltan elérhetőnek kell lennie.

OpenAIRE (https://www.openaire.eu): A projekt célja a nyílt hozzáférés népszerüsítése, és a széleskörü közzététel biztosítását elősegítő támogatási és elektronikus infrastruktúra és adatkezelési stratégia kialakítása. Az Európai Tanács kötelező érvénnyel rendelkezett meghatározott kutatási területeken a 7 . Keretprogramban támogatott projektek eredményeként született közlemények nyílt eléréséről intézményi vagy szakterületi repozitóriumokban. Ezeknek az intézményi és szakterületi repozitóriumoknak az adatait aratja és teszi közzé az OpenAIRE aggregátor szolgáltatása. Ahhoz, hogy az adatok begyüjthetők legyenek, a repozitóriumoknak „OpenAIRE kompatibilis"-nek kell lenniük. Az OpenAIRE kompatibilitás feltétele egyrészt a repozitórium regisztrálása az OpenDOAR nevü regiszterbe, másrészt a repozitóriumnak az OpenAIRE által definiált kimenő adatszerkezetet kell biztosítania.

Europeana (http://www.europeana.eu): ADEA tartalmai az Europeana Travel, az eCloud projektek, valamint a MANDA program közvetítésével jelennek meg az európai digitális könyvtárban az Europeana portálon keresztül. Az Europeana szintén OAI-PMH-n keresztül gyüjti be az adatokat. A megfelelő adatkezelés érdekében kidolgozták az ESE (Europeana Semantic Elements) szabványokat, melyek segítségével a metaadatok tisztítását készítik elő a duplumszüréshez.

\section{Helyi szabályozás}

A DEA fontos szerepet játszik az Egyetem tudományos kommunikációjában. A XXI. század elején a tudományos kutatás és disszemináció egyik legmeghatározóbb hívószava a nyílt hozzáférés. Az open access azt jelenti, hogy a tudományos irodalom az interneten keresztül ingyen és nyilvánosan hozzáférhetö, ezáltal az kutatók teljes szövegeket olvashatnak, másolhatnak, 
tölthetnek le és oszthatnak meg egymással, emellett kereshetnek a szövegekben, hivatkozhatnak azokra és bármilyen módon használhatják, anélkül hogy pénzügyi, jogi vagy technikai akadályokba ütköznének. Az open access mozgalom nemzetközi szintű megerősödése hozzájárul ahhoz, hogy egyre több intézmény teszi magáévá a nyílt hozzáférés politikáját. A kutatók ösztönzése mellett az intézmény feladata olyan kutatás-támogatási infrastruktúra kiépítése is, amely lehetőséget nyújt az egyetemi tudományos eredmények, és ezeken belül is az open access tartalmak begyüjtésére és hosszú távú megőrzésére.

A Debreceni Egyetem Szenátusa az egyetem tudományos küldetésének támogatása érdekében 2015 áprilisában „Szerzői jogi szabályzat és publikációs irányelveket" léptetett hatályba. A szabályzat célja szerzői müvek létrehozásának elősegítése a létrehozott szerzői müvek szerzői jogi aspektusainak szabályozásával; a tudományos publikációk hiteles nyilvántartásának biztosítása; a gazdasági és innovációs fejlődéshez való hozzájárulás azáltal, hogy az egyetem nyílt hozzáférést biztosít a tudományos eredményekhez. A szabályzat hatására az elmúlt közel egy év alatt 3000 fölé emelkedett a nyílt hozzáférésű publikációk száma az egyetemünk intézményi repozitóriumában, melyek a Tudóstér profilokból közvetlenül elérhetők.

\section{Verziófrissítés}

2014-ben új fejezet nyílt a DEA működésében a repozitóriumi keretrendszert adó DSpace nagy léptékű verzióváltása révén, amikoris az 1.5 verzióról 4.1-re váltottunk. Ez a folyamat több új változást is hozott magával. Kiegészítő fejlesztésekre volt szükség, hogy a meglévő, illetve kialakítandó gyüjtemények tartalomveszteség nélkül megjeleníthetők legyenek az új felületen.

Az új verzió számos funkcióval bővült, amelyek a repozitórium által nyújtott szolgáltatások minőségét javítják. Egy Solar alapú Discovery kereső segíti elő a gyors és hatékony tartalom előhívást. Lehetőség nyílt az embargó-kezelésre is, amely során a tudományos cikkek esetén a beállított embargó időszak lejártával a dokumentum automatikusan nyíltan elérhetővé válik az olvasók számára. A repozitóriumból kinyerhető statisztikai adatok spektruma is bővült. A DEA összekapcsolhatóvá vált a Google Analytics rendszerével, amely az oldal látogatottságára vonatkozóan szol- 
gáltat adatokat. Továbbá, saját fejlesztés eredményeként az új verzióval információt kaphatunk arról, hogy hányan látogatják az egyes tételek oldalait, illetve hány letöltés történik a repozitórium gyüjteményeiből.

A verzióváltás új struktúrát és új megjelenést is eredményezett. A gyüjtemények témák szerint lettek létrehozva, és a kiemelt, gyakran használt gyüjtemények színeiben is eltérően jelennek meg. Az új dizájn egy modernebb stílust tükröz, az oldalt a letisztultság és könnyü kezelhetőség jellemzi.

\section{Szabványok}

A repozitórium müködését, és az ehhez kapcsolódó fejlesztéseket számos nemzetközi szabvány határozza meg.

$O A I-P M H:$ Az interoperabilitás alapvető prokollját határozza meg. A tudásvagyon széles körben történő fejlesztéséhez elengedhetetlen, hogy a digitális adattárunk eleget tegyen a más szolgáltatásokkal való együttmüködéshez szükséges feltételeknek. Így fontos, hogy biztosítani tudja az automatikus módon történő adatcserét, melyhez szabványos kommunikációs csatornákat használ, és eleget tesz minden feltételnek, amit a külső szolgáltatások elvárnak. A projektekkel való együttmüködések során figyelni kell arra, hogy minden, a fogadó fél által elvárt metaadat átadásra kerüljön a megfelelő elemként és a megfelelő formátumban. Az adatszolgáltatók a szolgáltatást nyújtók számára biztosítják a metaadatokhoz való hozzáférést ezen módszer segítségével. A szolgáltatást nyújtó fél (Service Provider) le tudja kérdezni az adatszolgáltatónál (Data Provider) fellelhető adatokat, és automatikus kérést indíthat az adatok begyüjtésére, aratására.

SWORD: Ezt a protokollt a JISC támogatásával fejlesztették ki azzal a céllal, hogy kialakítsanak egy olyan egyezményes eljárást, mely lehetővé teszi elektronikus anyagok automatikus betöltését egyidőben több digitális repozitóriumba. Az interfész kialakításával lehetőség nyílt rá, hogy különböző helyekröl lehessen beemelni dokumentumokat az adattárba, akár az irodai programokból történő átemelés segítségével. Mi több, a protokoll segítségével lehetőség van arra is, hogy a betölteni kívánt anyagot egyszerre több adattárban is el tudjuk helyezni.

Shibboleth: A Shibboleth egy elosztott autentikációs rendszer, ahol a tartalmakhoz való hozzáférés az identitás-szolgáltatótól kapott jellemzők alapján történik. A felhasználó úgy vehet igénybe szolgáltatásokat a rendszeren belül, hogy csak egyetlen identitása van az „anyaintézménynél” 
(home institution). Mivel a Shibboleth általában tranziens azonosítókat használ, legjellemzőbb alkalmazási területei azok, ahol nem szükséges a felhasználó pontos kilétét megállapítani, hanem valamilyen jellemző csoporthoz tartozás alapján (például tanár egy bizonyos intézményben, hallgató egy adott kurzuson stb.) engedélyezett a hozzáférés. ${ }^{1}$

\section{Hogyan tovább?}

A DEA fejlesztése több fronton, folyamatosan zajlik. Rendkívül fontos az állandó népszerüsítés, a tudatosság kialakítása a felhasználók, az egyetem vezetése és a könyvtáros kollégák körében is. Újra és újra, újabb és újabb érvekkel kell felkelteni az érdeklődést az új szemléletmódot feltételező szolgáltatás iránt. Szükség van valamennyi dokumentum és gyüjtemény jogi körülményeinek tisztázására: a feladat ellátását nehezíti a szabályozás többféle értelmezhetősége, illetve hiánya egyes dokumentumoknál.

Az átalakítás első évének tapasztalatai alapján elkezdődhet az archívum munkafolyamatainak szabályozása, licencrendszerének átdolgozása, valamint a DEA gyüjteményépítési stratégiájának, archiválási politikájának és eljárásrendjének kialakítása. Elengedhetetlenné vált az állandó személyzet, repozitórium-üzemeltető csoport biztosítása a szolgáltatás rendszerbe való integráláshoz, a metaadatok gondozásához és a közönségkapcsolatok fejlesztéséhez.

\section{Rezümé}

A Debreceni Egyetem repozitóriuma (DEA) 2006 tavaszán jött létre. A müködésének tizedik évfordulóját számos változással ünnepeltük meg: verziófrissítést, új arculat kialakítását, és az archívum szerkezetének radikális újragondolását végeztük el. Az archívum technikailag és tartalmilag is szorosan összefonódik az Egyetem rendszerével. Struktúrája, tartalmi egységei, autentikálási rendszere az egyetemi informatikai fejlesztésekkel összhangban lett létrehozva. A DEA számos nemzetközi program és projekt aktív résztvevője is, amelyek a nemzetközi repozitórium-hálózat fejlesztését, az akadálymentes szabványos adatcserét és információhoz való korlátlan hozzáférést tủzték ki célul. Az innováció és a hálózatosodás jegyében a Debreceni Egyetemi repozitóriumi fejlesztések olyan irányba mutatnak, ahol a hosszú távú és fenntartható müködést a hazai és nemzetközi szabványoknak való megfelelés, illetve az Egyetemi Könyvtáron belül egy állandó repozitóriumi fejlesztő és szolgáltató csapat biztosítja.

${ }^{1}$ Bajnok Kristóf: Autentikációs és autorizációs infrastruktúrák. = Híradástechnika, 61. évf. 2006. 6. sz. 29-34. p. 


\section{The Electronic Archive of the University of Debrecen (DEA)}

The repository of the University of Debrecen was established in 2006. The 10th anniversary of its foundation is celebrated by numerous changes: software update, new design and a structural transformation. The repository is closely linked to the IT system of the University both in content and technological setup: the structure, collection units and authentication system have all been created in line with the university developments. The repository also actively participates in international programs and projects which aim at expanding the global repository network, a barrier-free data exchange and open access to information. In order to advance innovation and networking, the developments of the university repository wish to achieve a long-term, sustainable operation by corresponding to international standards and by organizing a library team responsible for the database developments and services.

KARÁCSONY GYÖNGYI

föigazgató

DEENK 